\title{
Intervention Supportive Educative System Based on Self Care and Family Centered Nursing Model to Family Support in Teaching Cough Ethics and Correct Sputum Disposal of TBC Patients at Sanggau Ledo Health Center, Bengkayang District
}

\author{
Tri Wahyuni ${ }^{1}$, Parliani ${ }^{2}$, Cau Kim Jiu ${ }^{3}$, Kharisma Pratama ${ }^{4}$, Tutur Kardiatun ${ }^{5}$, Sukartina ${ }^{6}$ \\ 1,2,3,4,5,6STIK Muhammadiyah Pontianak, Indonesia \\ Email:tri@stikmuhptk.ac.id
}

\begin{abstract}
:
Tuberculosis is an infectious disease that attacks the lungs characterized by granuloma formation and causes tissue necrosis, a direct infectious disease caused by the TBC germ (mycobacterium tuberculosis). Problems that often arise in tuberculosis sufferers are about knowledge, activities and psychosocial family support. Purpose: this study was to determine a supportive educative system intervention based on self-care and family centered nursing models for family support in teaching cough and sputum disposal properly. Methods: The research design used was quantitative with a Quasi Experimental design pre-test post-test without control group. The sample in this study was 20 samples taken before and after the intervention. Results: based on the bivariate analysis of knowledge, activity, and family support with the Wilcoxon test, it shows that in the intervention group after education, this self-care based system affects people with tuberculosis, the variable knowledge with $p$ value 0,000 , activity (behavior) with $p$ value 0,000 and family support $p$. value 0.050 , which means $p$ value $<a$ 0.050, this study shows that there is a difference in scores of supportive educative system interventions based on self-care and family centered nursing models on family support in teaching cough and sputum disposal properly. Suggestion: This study recommends that poly pulmonary health services provide a supportive educative system intervention based on self-care and family centered nursing models for family support in teaching cough and sputum disposal in TBC patients.
\end{abstract}

Keywords:

education; self care; tuberculosis

\section{Introduction}

Health is a very important element of the quality of life in national development. The national health system has established that the goal of health development is to increase awareness, willingness, and ability to live healthy for everyone so that a high degree of public health can be realized - high human resources, as an investment for socially and economically productive development. -Health Law No. 36 of 2009. (Hasibuan, 2020).

Occupational Health and Safety or K3 is a science, art and technique to be appliedin workingso that the work carried out is free from risks that can result in health problems, work accidents, explosions, burning, and air pollution in the workplace. Or the essence of Occupational Health and Safety or K3 definition is accident prevention (Silaban, in Wahyudi, 2020). 
Tuberculosis is an infectious disease that attacks the lungs which is characterized by the formation of granulomas and causing tissue necrosis $(\mathrm{MOH}, 2013)$. It has been known for more than a century, namely after the discovery of the TBC germ by Robert Koch in 1882, however until now TBC disease remains a global health problem and challenge at the world level and in Indonesia. (Ministry of Kesehan Republic of Indonesia, 2010). Direct infectious disease caused by the TBC germ (mycobacterium tuberculosis) (Black \& Hawks, 2014).

Based on data from the World Health Organization (WHO), in 2013, 9 million people in the world have been infected with TBC germs (WHO, 2014). In 2014 there were 9.6 million people in the world infected with TBC germs (WHO, 2015) and the highest number of cases of pulmonary tuberculosis was in the African region (37\%), Southeast Asia (28\%) and the East Mediterranean region (17\%), (WHO, 2015).

In Indonesia, the prevalence of pulmonary tuberculosis is grouped into three areas, namely Sumatra (33\%), Java and Bali (23\%), and eastern Indonesia (44\%) (Depkes, 2008). Pulmonary tuberculosis is the third leading cause of death after heart and respiratory disease in all age groups and number one for infectious diseases. The death toll from pulmonary tuberculosis in Indonesia is estimated at 61,000 deaths each year (Depkes RI, 2011). The success of treatment in Indonesia is still below WHO standards, namely 85\% and Indonesia is still 81.3\% (Ministry of Health, 2015).

In West Kalimantan, the prevalence of TBC incidence rate in 2013 was the most with positive AFB in the 45-54 years age group, namely $20.54 \%$ of 973 patients. In 2014, the highest number of TBC was in the 45-54 years age group, namely $20.29 \%$ of 833 patients and in 2015 . New patients and tests according to age in West Kalimantan Province 2015 experienced the most shift in TBC sufferers in adolescents with the age group 25 - 34 years, namely $20.53 \%$ of 638 . The high incidence and prevalence, especially TBC cases, is a serious threat of transmission in the community, because the source of TBC transmission is TBC sufferers and the success of treatment in West Kalimantan is still relatively low (Dinkes Kalbar, 2015).

The Puskesmas Sanggau Ledo, Bengkayang District, is an inland health center that has never received explanation on self-care theory for TBC patients in providing services for pulmonary TBC cases. At the Sanggau Ledo Health Center, TBC disease is the number 3 of the 10 most outpatient diseases. (Register of Puskesmas Sanggau Ledo, Bengkayang Regency, 2019). The impact of mycobacterium tuberculosis that lodges in the respiratory tract will cause damage, especially to the lung area, will cause nursing problems, the risk of spreading infection to other organs and spreading to other people. Nursing problems often arise in TBC patients with nutritional disorders, activity intolerance, faculty and psychosocial problems (Black \& Hawks, 2014: Dongoes, 2014).

Handling efforts have been carried out by government programs but the problem of treatment is hampered because in TBC cases the treatment is long enough in the intensive phase of 2 months and a follow-up phase of 4 months. A minimum conversion target of $80 \%$ in the intensive stage (PDPI, 2017). A related study was conducted by (Caesar, 2014) regarding the difference in the effect of fixed-dose combination anti-tuberculosis (OAT) drugs compared to release on the conversion of acid-resistant bacillus sputum at the end of the intensive phase. In tuberculosis patients, it was found that there was no significant difference between OAT KDT compared to the release of sputum BTA conversion ((acid-resistant bacteria) at the end of the intensive phase in adult TBC patients $(\mathrm{p}=0.644)$. Treatment is effective if it is supported by family support in TBC patients. 
Based on this, this is in accordance with the results of research (Nurhidayati, 2016) regarding the role of the family in taking medication for TBC sufferers in Kawedanan Pedan Klaten with 44 respondents with the results of the study (34.1\%) good family support and (3.6\%) categories poor family support with value $(\mathrm{p}=0.000)$. The role of family is very important in the treatment of meeting the nutritional needs of TBC patients.

Based on research (Pertiwi, 2012) the relationship between individual characteristics, environmental hygiene and sanitation practices with the incidence of tuberculosis in North Semarang sub-district with 30 respondents from the research results of the habit of not covering their mouths when coughing $(56.7 \%)$ and the habit of throwing sputum in any place $(86,7 \%)$. From this study, it can be concluded that the contact history of pulmonary tuberculosis patients at home and work environment is a risk factor for the incidence of pulmonary tuberculosis.

Efforts to overcome nursing problems that occur in TBC patients are carried out by increasing the support of patients as the main support for families and health workers. Interventions carried out by patients as agents for themselves are known as (self care). Self care was developed by Orem, 1971 in (Alligood, 2014) which states that nursing care is carried out with the belief that everyone has the ability to care for them so that they help individuals meet their life needs, maintain their health and well-being, known as self care. Self-care in TBC patients can be done to overcome nursing problems that arise by preventing the spread of infection, increasing treatment, increasing nutritional needs and overcoming psychosocial problems so that recovery can be achieved.

A person's self-care ability is needed by a care giver. Based on research (Trirahayu, 2016) on increasing the implementation of family health tasks in tuberculosis care through selfmanagement education with 34 respondents, the results of research by family health workers in the care of pulmonary tuberculosis patients after carrying out the pulmonary tuberculosis selfmanagement education package in the control group had an average of 25, 59 and in the intervention group 43.29 the mean difference was 17.70 with $(p=0.001)$ and $(\alpha=0.05)$. So that nurses' assistance is needed in providing education to caregivers about pulmonary tuberculosis.

Health education or education is a series of learning that is carried out in a planned manner, based on logical theories and equips individuals, groups and society to influence others, obtain information and skills to make quality health decisions in order to improve healthy living standards and community welfare. (Notoatmojo, 2012). This is in accordance with research conducted by (Ummami, 2016) regarding the effect of health education on the knowledge and attitudes of sufferers in preventing tuberculosis transmission at the SIMO Boyolali Community Health Center, Central Java. The results obtained were an increase in knowledge and attitudes after education (Pvalue: $<0.05$ ). One of the educational companion media can use a supportive educative system intervention based on self care and family centered nursing models for family support.

Based on the above explanation, the researcher felt the need to conduct research on "Intervention of supportive educative system based on self-care and family centered nursing model for family support in teaching cough ethics and proper disposal of sputum to TBC patients at the Sanggau Ledo Community Health Center, Bengkayang Regency". 


\section{Review of Literature}

Tuberculosis is an infectious disease with an increasing number of sufferers in the world and in Indonesia, including in Pontianak. Management to overcome nursing problems that arise can be done by involving patients to care for themselves or known as (self care).

Self care for TBC patients can be done by increasing the rate of recovery by providing ventilation through effective breathing and coughing exercises, medication and increasing knowledge. Increasing knowledge can be done through education and monitoring. The use of monitoring as can be developed in this self-care management, through monitoring efforts by the patient's family. Based on the description above, the formulation of the problem in this study is whether there is an effect of supportive educative system intervention based on self care and family centered nursing model on family support in teaching cough ethics and proper disposal of sputum to tuberculosis patients at the Sanggau Ledo Community Health Center, Bengkayang Regency "?

\subsection{General Purpose}

Knowing the effectiveness of self-care based supportive educative system interventions and family centered nursing models for family support in teaching cough ethics and proper disposal of sputum to tuberculosis patients at the Sanggau Ledo Community Health Center, Bengkayang Regency"

\subsection{Special Purpose}

1) Identified characteristics of respondents' age, education level, occupation at the Puskesmas Sanggau Ledo Bengkayang Regency "Identified self-care activities (behavior) of TBC patients before and after.

2) Identified self care family support for TBC patients before and after supportive educative system intervention based on self care and family centered nursing model.

3) Identified self care knowledge of TBC patients before and after supportive educative system intervention based on self care and family centered nursing model.

4) Identified self-care activities of TBC patients before and after education with a supportive educative system intervention based on self care and family centered nursing models.

5) Identified the effect of self care before and after education with a supportive educative system intervention based on self care and family centered nursing models.

\section{Research Method}

This research is a research using a quasi-experimental design with a non-randomizer pretest design without control group (Sugiyono, 2009). In this study, a test was conducted before the respondent was given treatment. The test was carried out by measuring self-care carried out on TBC patients using the interview method and questionnaire measuring instrument (Notoatmodjo, 2010). The form of research design was a quasi-experimental method by looking at the scores before and after the treatment using self-care guidance intervention.

In this study, the subjects taken by the researcher were all tuberculosis patients, patients who checked themselves in the pulmonary clinic at RSUD DR.Soedarso Pontianak, West Kalimantan, patients who were still able to communicate well and pa tients who were undergoing intensive and advanced phase treatment. 


\section{Discussion}

Table 1. Univariate Analysis

\begin{tabular}{llcc}
\hline No & Respondent Characteristics & Total & Percentage \\
& Gender & & \\
$\quad$ Male & 9 & $45 \%$ \\
$\quad$ Female & 11 & $55 \%$ \\
$\quad$ Age & & \\
$\quad$ 20-29 Years & 5 & $25 \%$ \\
& 30-39 Years & 4 & $20 \%$ \\
$\quad$ 40-49 Years & 5 & $25 \%$ \\
$\quad$ 50-59 Years & 6 & $30 \%$ \\
3 Education & & \\
$\quad$ Primary School & 8 & $40 \%$ \\
$\quad$ Junior High School & 3 & $15 \%$ \\
$\quad$ Senior High School & 9 & $45 \%$ \\
$\quad$ Higher Education & 0 & $0 \%$ \\
$4 \quad$ Occupation & & \\
$\quad$ Not Work & 2 & $10 \%$ \\
$\quad$ Farmer & 8 & $40 \%$ \\
$\quad$ Private employees & 9 & $45 \%$ \\
$\quad$ Civil servants & 1 & $5 \%$ \\
\hline
\end{tabular}

Based on gender, age, education and occupation of TBC patients at the Sanggau Ledo Community Health Center, Bengkayang Regency $(n=20)$, November 2019-January 2020. Based on the table above, the data shows that the average respondent is 11 women $(55 \%)$. Based on age, most respondents are in the age range of 50-59 years of 6 people (30\%) with an educational background, namely high school as many as 9 people (45\%) and work as private employees by 9 people $(45 \%)$.

\subsection{Variable Data Distribution}

Table 2. Distribution of Knowledge, Attitudes and Activities Data

\begin{tabular}{lllll}
\hline No & Variable & $\begin{array}{l}\text { Min- } \\
\text { Max }\end{array}$ & Mean & $\begin{array}{l}\text { Primary } \\
\text { School }\end{array}$ \\
1 & Knowledge & & & \\
& $\begin{array}{l}\text { Before } \\
\text { After }\end{array}$ & $\begin{array}{l}7-19 \\
28-\end{array}$ & 12,55 & 3,441 \\
& & 36 & & \\
2 & Attitude & & & \\
& Before & $12-$ & 16,05 & 2,564 \\
& After & 20 & 39,00 & 12,486 \\
& & $17-$ & & \\
& & 57 & & \\
3 & Activity & & & \\
& Before & $4-8$ & 5,85 & 1,694 \\
& After & $4-18$ & 13,35 & 4,254 \\
\hline
\end{tabular}


Based on table 4.2, the data distribution of the knowledge variable obtained the knowledge score after intervention was greater with a mean value of 33.50 than the mean value of knowledge before the intervention was 12.55 . In the attitude variable, it was also found that the attitude score after intervention was greater with a mean difference of 23.05. While the activity variable after intervention was also greater with a mean value of 13.35 with a standard deviation of 4.254 .

Table 3. Results of Variable Willcoxon Measurement

\begin{tabular}{llccccc}
\hline No & Variable & $\begin{array}{c}\text { Negative } \\
\text { rank }\end{array}$ & $\begin{array}{c}\text { Positive } \\
\text { rank }\end{array}$ & $\begin{array}{c}\text { Mean } \\
\text { rank }\end{array}$ & Ties & $\begin{array}{c}p \text { - } \\
\text { value }\end{array}$ \\
1 & Knowledge & 0 & 20 & 10,50 & 0 & 0,000 \\
2 & Attitude & 0 & 19 & 10,00 & 1 & 0,000 \\
3 & Activity & 0 & 18 & 9,50 & 2 & 0,000 \\
\hline
\end{tabular}

\subsection{Willcoxon Variables Measurement Results for Knowledge, Attitude and Activity}

The results of the Willcoxon measurement on the knowledge variable increased in value after the intervention of 20 people with an average increase in value of 10.50 . While the attitude variable of 1 person has the same value and for the activity variable there are 2 people with the same value or there is no change in value, but of the three variables there are no respondents who experience a decrease in value. The measurement results also show that there is a mean difference between before and after the intervention on the variables of knowledge, attitudes and activities or in other words it states that the alternative hypothesis is accepted with a p-value of $\neg 0,000$ on the three variables.

\section{Conclusion}

1. Male sex is 9 people $(45 \%)$ and female is 11 people $(55 \%)$.

2. Age 20-29 5 people (25\%), 30-39 years old 4 people (20\%), age 40-49 years 5 people $(25 \%)$ and aged $50-59$ years 6 people $(30 \%)$.

3. Education level of SD 8 people (40\%), SMP 3 people (15\%) and SMA 9 people $(45 \%)$.

4. Status of employment Not working 2 people (10\%), farmers 8 people (45\%), private employees 9 people $(55 \%)$ and civil servants 1 person (5\%).

5. There are differences in self-care knowledge of TBC patients after treatment, the $\mathrm{p}$ value is 0,000 .

6. There are differences in self-care activities (behavior) in TBC patients after the treatment obtained $\mathrm{p}$ value 0.000 .

7. There are differences in self-care family support in tuberculosis patients after using the booked treatment.

\section{Suggestion}

1. For Community Service

Community nurses and family nurses who have direct contact with the community can socialize with the community and families so that they can try self-care interventions for TBC patients by consulting with health workers at the nearest health center to control independence in TBC patients.

2. Education and Development of Nursing Science

As the development of medical surgical nursing science, it can be an additional study in a subject that can be applied as evidence based practice to students in their respective institutions. 


\section{Further Research}

Researchers can then examine the focus on the intensive phase to compare the effectiveness of educational measures on self-care for TBC patients.

\section{References}

Alligood, M.R. \& Toemy, A.N. (2019). Register Poli Paru Puskesmas Sanggau Ledo. Kalimantan Barat. Alligood, M.R. \& Tomey, A.N. (2017). Nursing Theorist and their workn Edition 2, ST. Louis: Mosby Elsevier, Inc. Singapura

Black Joyce M. (2014). Keperawatan Medikal Bedah. Singapore:. PT Salemba Emban Patria. Elsevier. CAN, (2013).Teleherth: the role of the nurses. Retrieved April 2017, from www.cnaaiic.ca:http://www.cnaaiic.ca/ /media/cna/page\%20content/.../ps89_teleherth_e.pdf

Depkes RI. (2007). Pedoman penanggulangan tuberkulosis di Indonesia (PPTI).Jakarta: Depkes RI

Depkes, RI. (2010). Pedomanpenanggulangan tuberkulosis di Indonesia (PPTI).Jakarta: Depkes RI 2011. Pedoman penanggulangan tuberkulosis di Indonesia (PPTI).Jakarta: Depkes RI

Dinas Kesehatan Kabupaten Pontianak, (2015). Laporan Program Penanggulangan TBC Kabupaten Pontianak. Tabun 2013-2015. Kalimantan Barat

Dermawan, D. dan Riyadi, S. (2010), Keperawatan Profesional, Yogyakarta : Gosyen Publising.

Durrani, H \& Khoja. (2009). A systematic review of the use of telehealth in Asian countries. Journal of Telemedicine and Telecare 2009; 15: 175-181. Diakses melalui www.proquest.com tanggal 19 Maret 2017.

George et al. (2008). How safe is telenursing from home?. Australian Journal of Advanced Nursing, Volume 26 Number 1:26-31. Diakses melalui www.proquest.com tanggal 19 Maret 2017

Hasibuan, S.,M. et al. (2020). Relationship of Family Income and Family Support with Maternal Reference in Pregnant Women in Pantai Cermin BEmONC, Langkat District, 2019. Budapest International Research and Critics Institute-Journal (BIRCI-Journal). P. 486-493

Hidayati, (2015). Pengetahuan dan Stigma Masyarakat terhadap TBCC Setelah Diberikan Pendidikan Kesehatan Pencegahan dan Penularan.Fikes UNSOED. Sumatra Barat

Hoglund et al. International Journal for Equity in Health (2016) DOI 10.1186/s12939-016-0447-0, London. tanggal 19 Maret 2017.

Irfan, M. (2011). Telenursing Sebagai Trend dan Issu Pelayanan Keperawatan Indonesia di Tabun 2020. Analisis Teknologi Informasi Manajemen Kesehatan. Tesis tidak diterbitkan. Jakarta: Magister Ilmu Keperawatan Universitas Indonesia

Nurhidayah, R. E. (2009). Pendidikan Keperawatan. Medan: USU Press

Nurliawati, (2016). IbM Pencegahan Tuberkulosis. Volume 2. STIKes Bakti Tunas Husada, Tasikmalaya, Jawa Barat

Nursalam, (2008). Konsep dan penerapan metodologi penelitian keperawatan. Jakarta: Salemba Medika

Notoatmodjo, Soekidjo. (2007). Promosi Kesehatan Teori dan Aplikasi. Jakarta: Rineka Cipta.

Nurgroho Septian Adi, (2012). Hubungan Antara Pengetabuan Penderita Tuberkulosis dan Dukungan Keluarga dengan Kepatuhan Minum Obat di Wilayah Kerja Puskesmas Jekulo Kabupaten Kudus. Jawa Tengah

Nurhidayati Istiana, (2016). Peran Keluarga Pada Kepatuban Minum Obat Penderita TBC di Kawedanan Pedan Kelaten. Stikes Muhammadiyah Klaten

Pedoman dignostik \& Penatalaksanaan Penyakit Paru di Indonesia (Konsenseus Paru), (2008). Jakarta

Potter, P.A, Perry, (2010) A.G.Buku Ajar Fundamental Keperawatan : Konsep,. Proses, dan Praktik.Edisi 4.Volume 2.Alih Bahasa : Renata. Komalasari,dkk.Jakarta:EGC.

P. Puspa, (2016). Tingkat Kepatuhan Pengunaan Obat Pada Pasien Tuberkolosis Di Rumah Sakit Mayjen H. A. Thalib Kabupaten Kerinci. (Online), Vol 2 No2, (http://jsfkonline.org/index.php/jsfk/article/view/60/pdf, Diakses 1 Maret 2017) 
Prayitno, (2010). Pusat Penelitian dan Pengabdian Kepada Masyarakat / LPPM Research and Community . UNAIR Surabaya.

Scotia. (2008). Telenursing practice guideline. College of Registered Nurses of Nova Scotia. Diakses melalui www.proquest.com tanggal 19 Maret 2017.

Stallings, William, (2010), Komunikasi dan Jaringan Nirkabel, Jakarta, Erlangga.

Smeltzer, S., \& Bare. (2008). Buku ajar keperawatan medikal bedab brunner \& suddarth vol 1 edisi 8 , Jakarta: EGC.

Sugiyono. (2009). Statistika Untuk Penelitian. Bandung: Alfabeta.

Wahyudi, J., Silaban, G., and Aulia, D. (2020). The Relationship between Motivation Factors and Unsafe Action on Passenger Ship Crews in Tanjung Pinang. Britain International of Exact Sciences (BIoEx) Journal Vol. 2 (1):390-404.

Wilkinson, J.M., \& Ahern N.R., (2012). Buku Saku Diagnosis Keperawatan Diagnosa NANDA Intervensi NIC Kriteria Hasil NOC Edisi kesembilan. Jakarta: EGC.

World Health Organization, (2011). Global tuberculosis control: WHO report(WHO / HTM /TBC /2013 .11). Geneva 